\title{
SYSTEMIC NON-MALIGNANT OSTEOPOROSIS AND REDUCTION OF EDENTULOUS ALVEOLAR RIDGES
}

\author{
Poštić D. Srđan, ${ }^{1,2,3}$ Vujasinović Stupar Nada, ${ }^{4,5}$ Asotić Mithat, ${ }^{3}$ Rakočević Zoran, ${ }^{1,6}$ \\ ${ }^{1}$ Belgrade University, Faculty of Dental Medicine, Belgrade, Serbia \\ ${ }^{2}$ Clinic of Dental Prosthetic, Belgrade, Serbia \\ ${ }^{3}$ University of Travnik, Pharmaceutical-health Faculty, Federation of Bosnia and Herzegovina \\ ${ }^{4}$ Belgrade University, School of Medicine Belgrade, Serbia \\ ${ }^{5}$ Institute of Rheumatology, Belgrade, Serbia \\ ${ }^{6}$ Institute of Radiology, Belgrade, Serbia
}

Primljen/Received 01. 09. 2013. god.

Abstract: Introduction. Systemic osteoporosis damages skeletal bones to different degrees.

The aim of this study was to determine the intensity and correlation of the osteoporotic changes in the bone density of the skeleton and body mass index (BMI) with a reduction in edentulous mandibles, and to assess possibility of reparation of layers of mandibles with increase of mineral content in jaws of patients affected by osteoporosis.

Material and Methods. In this study, 99 edentulous patients with decreased bone density comprised the experimental group, and 48 edentulous patients with normal bone densities formed the control. The age of the examined patients was $69.02 \pm 7,9$, range 53-74 of females and $69.11 \pm 7.1$, range 59-76 years. Radiographs of the hands and panoramic radiographs were done for all the patients. The values of BMI, metacarpal index, density of lumbar spine (L2-L4), in the phalanx and in segments of the mandibles as well as the edentulous alveolar ridges heights were measured, assessed and calculated.

Results. The lowest value of the total skeletal density was established in the osteoporotic patients on the basis of the average T-score of -2.5 in men, and -2.6 in women. Minimum values of the edentulous ridges heights (right/left, in $\mathrm{mm}$ ) were measured in both osteoporotic females (21.84/22.39) and males 24.90/24.96) patients. By comparison of the densities of the metacarpal bones, proximal phalanx, segments of the edentulous mandibles and based on the numerical values of the edentulous ridges heights, $\chi^{2}=3.81$ was found in men and $\chi^{2}=4.03$ was found in women with normal
Prihvaćen/Accepted 17. 01. 2014. god.

bone densities; $\chi^{2}=5.92$ was found in men and $\chi^{2}=$ 6.25 was found in women with osteopenia; $\chi^{2}=2.63$ was found in men and $\chi^{2}=3.85$ was found in women with osteoporosis, on the level of probability of 0.05 . After application of calcium and calcitonin in solutions, moderate increment of density $(p<0.05 ; p<0.01)$ was verified, compensating up to $4 \%$ of total loss of mass, minerals and solidity of denture bearing areas of osteoporotic mandibles.

Conclusion. Systemic osteoporosis leads to decrease of densities of bones of mandibles and causes reduction of edentulous ridges.

Key words: osteoporosis; mandible; stomatognathic system; density; mineral content; bones.

\section{INTRODUCTION}

Osteoporosis decreases bone mass $(1,2,3)$. Also, osteoporosis increases bone fragility $(1,2,3)$.

Systemic osteoporosis has a greater influence to quality and quantity of jaw bones than expected when compared to the influence of local factors among which loss of a tooth is the prevailing one (4-9). However, there is still controversy concerning whether osteoporosis significantly reduces edentulous alveolar ridges $(8,10,11,12)$, or whether its impact on the jaw reduction is insignificant $(13,14,15)$. Also, the results based on the previous studies showed the significant role of the metabolic factors and osteoporosis in the initiation of the reduction of the edentulous residual alveolar ridges (10).

Reduced blood flow to the jaw - particularly in the lower jaw and difficulty in circulation associated 
with systemic osteoporosis can cause loss of bone substance in the edentulous residual alveolar ridges (16, 17). In addition, if there are signs of alveolar bone reduction under a denture that fits comfortably in the intimate underlying tissue, the causes, in the first place, should be sought in action and influence of systemic osteoporosis $(18,19)$.

Metabolic disturbances and systemic osteoporosis are directly responsible for the appearance of manifested reduction in the residual alveolar ridges of the maxilla and mandible (20).

In many of these studies the panoramic radiographs were used, which is confirmed in the literature as the correct approach in the diagnosis and therapy for many diseases of the stomatognathic region of edentulous patients as well as in dentate patients (21).

A low BMI has also been described as one of the risk factors that may indicate the beginning or the presence of atrophy and reduction of the alveolar ridges, with the fact that patients with low bone mineral density (BMD) may not always have reduced edentulous alveolar ridge, and vice versa. It is also acceptable that patients without supple bone structure and anatomically minor dimensions of the bones usually have significantly marked signs of atrophic jawbone when compared with a subject with normal BMD $(22,23,24,25)$.

The aim of this study was to determine the intensity and correlation of the osteoporotic changes in the bone density of the skeleton and body mass index (BMI) with a reduction in edentulous mandibles, and to assess possibility of reparation of layers of mandibles with increase of mineral content in jaws of patients affected by osteoporosis.

\section{MATERIAL AND METHODS}

In this research 147 edentulous subjects, aged from 53 to 73 years, were examined. A study group consisted of 99 edentulous patients (39 men and 60 women) with low bone density, based on data obtained by densitometry of lumbar vertebral bodies, and control group consisted of 48 edentulous patients ( 25 men and 23 women) with normal bone density (Table 1).

In order to collect data, the parameters of weight (in $\mathrm{kg}$ ) and height (in $\mathrm{cm}$ ) were measured, to provide information on body mass index (BMI) of every patient. Antero-posterior radiographs of hands (APCR) (Siemens Rtg apparatus, tube Dofoks RX 150/30-50, focus $2 \mathrm{~mm}$ ), and standardized panoramic radiographs (Kodak T-MAT G) of all patients were taken in accordance with predetermined distance on a scale on the plastic chin-holder of the panoramic X-ray unit (Orthopantomograph 10, Serial No. 01492, Siemens, Germany) under the determined conditions (68 KV and 5 $\mathrm{mA})$. After collecting data on BMI, the most important analyses on skeletal densities at systemic level were provided on the basis of scanning of lumbar vertebrae (Lunar DPX-L scanner, USA). Analyses of changes of qualities and quantities of bones of interest were done taking into consideration four parameters: body mass index (BMI), metacarpal index (MI), heights (in $\mathrm{mm}$ ) of edentulous mandibular ridges (VBG) respecting areas where molars were previously extracted and densities of spongy parts of metacarpal bones, proximal phalanx, as well as edentulous ridges of mandibles.

The parameter MI was calculated based on the measurement of the differences between the width of trabecular-spongy part of the bone and the width of the cortical bone in the middle segment of the second metacarpal bone according to the formula: MI equals width of the spongy portion minus cortical thickness divided with the numerical value of the overall diameter of the middle shaft of the second metacarpal $(2,50)$.

The region of the lower jaw was determined in this study for measurements of both of bone density and edentulous ridge height. Transparent films with mesh (squares of dimension $2 \mathrm{~mm} \times 2 \mathrm{~mm}$ ) were then positioned onto each of the panoramic radiograph of each patient. Numerical values of the digital light-optical densities were recorded using a densitometer (DT 11 05, England) by transmission of a light beam through each square of the region of interest. In the assessment of the quality of bone of each of the subject examined BMI, densities of a skeletons $\left(\mathrm{g} / \mathrm{cm}^{3}\right)$ (Lunar DPX-L'GE Healthcare, Piscataway, NJ,USA), and densities of mandibles on the basis of measurements on panoramic radiographs and digital densitometer were considered.

The procedure of measurement and calculation was performed as follows:

The absolute density of the extracted segment of the jaw bone, as measured by the pycnometer was in the range of values of $0<\rho<0.95 \mathrm{~g} / \mathrm{cm}^{3}$.

Bone density was measured using a digital densitometer. It was measured in the range $-3<\mu<3$, because the value of a digital densitometer depicted in the range of -3 to $+3 \mathrm{U} / \mathrm{mm}^{2}$.

In calculating the values of bone density in arbitrary units corresponding to a determined and specified values of absolute density $\mathrm{g} / \mathrm{cm}^{3}$ (ie $\mathrm{mg} / \mathrm{cm}^{2}$ ) general formulas were applied with a coefficient equations $(\mu)$ and two unknowns $(\mathrm{a}+\mathrm{b}), \mathrm{F}=\mathrm{a}+\mu \mathrm{b}$. To determine values measured using the pycnometer the formula was $\rho$ $=\rho o+\mathrm{c} \mu$. Value $\mathrm{c}$ is calculated from the quotient value $=0.956 \mathrm{c}$, where $\mathrm{c}=0.95: 6$. calculating the procedure is then applied to the calculation of the value of formulas $3-1.05+c \mu=\rho o$ and $\rho o=(3 \times 0.95) 6$, so that the established basic value was $0=\rho 0-3 \mathrm{C}$.

Calcitonin (Miacalcic, Novartis, Switzerland), and calcium (Calcium-gluconate Sterop, Belgium; Calci- 


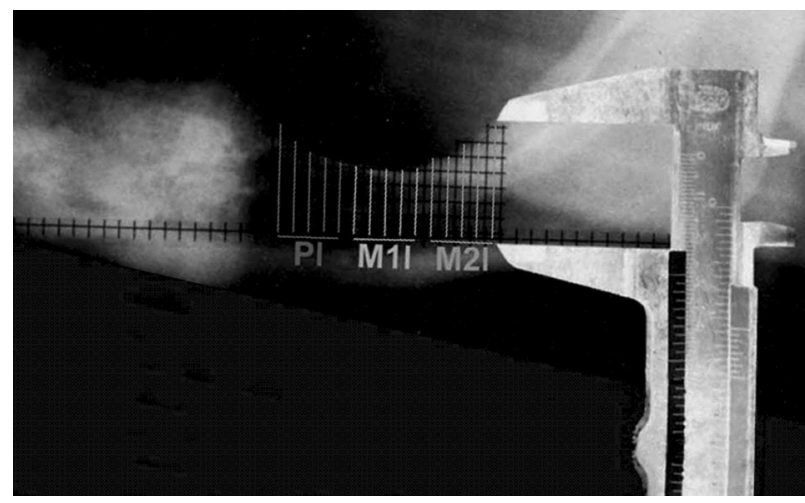

Figure 1. Segments of interest in mandible

um-Sandoz 10\% calcium glubionas amp., Switzerland) were used locally to improve solidity of oral bones in fifty three osteoporotic edentulous patients - 11 men, aged 64 to 75 yrs. (mean age 71 yrs.) and 42 women, aged 55 to 75 yrs. (mean age 56 yrs.) of the experimental group. Thirty seven edentulous patients -17 men, aged 55 to 75 yrs. (mean age 59 yrs.), and 20 women, aged 45 to 56 yrs. (mean age 55 yrs.), with well pronounced edentulous ridges after extractions of teeth and with normal bone density, were controls. Patients were selected concerning dental history, questionnaire on previous medical treatments of osteoporosis, skeletal density, history of fractures of any of bones, menopausal periods in women, calcium and microelements of blood-plasma, as well as oral status on bone consistency or reduction. Patients had not manifested destructions in the mouth because of malignancy. After local application of anaesthetic, submucosal injection of up to $1.5 \mathrm{ml}$ of solution containing calcitonin and calcium (2:1 ratio in one dose) has been administered $(26,27,28)$. This solution was injected towards mandibular bone surfaces (Figure 1). Total of six doses to the right side of osteoporotic mandible and six doses to the left side of bone were administered in each patient of the experimental group. Regions of interest were determined on the basis of assigning of reference line under the base of mandible, as well as according to determining of vertical lines. Region Pr was determined regarding area of bone where roots of the second premolars were missing. Region M1r was determined for areas in which roots of the first molars were missing after extractions, and region M2r was determined on the basis of areas without roots of the second molars. Using the same parameters and reference lines, regions $\mathrm{Pl}, \mathrm{M} 11$ and M21 were determined. Measurements of density of mandibles have been done after 4 months of administration of solution of calcitonin and calcium and after 6 months. T scores were applied for analysis of density of bone of experimental group patients, at systemic level.

Three questionnaires were designed for the patients in the experimental group in this study. The first questionnaire aimed to learn what the patients thought about their old dentures before therapy by calcitonin and calcium. The second questionnaire aimed to document what the patients thought about their dentures after therapy by calcitonin and calcium. The patients were asked to rate their dentures as good, fair, or poor in the categories of retention, ability to chew, and comfort. Each item was scored on the basis of good $=3$, fair $=2$, and poor $=1$. Total score was termed the "Patient satisfaction score".

The third questionnaire was provided for the dentist to evaluate the technical quality of the complete dentures that were fabricated for the patients immediately after therapy. The scoring of denture quality was on the same scale as for questionnaires 1 and 2 .

\section{Statistics}

For statistical calculations of numerical values of densities of bones, mean values and standard deviations were initially calculated. In statistical processing of numerical values of heights of edentulous ridges, mean values, standard deviations and coefficients of variations were used. Correlations of radiologic representation of height of edentulous ridge Y1 on panoramic radiographs and digital optical densities of determined segments of mandibles were estimated by Pearson's index of correlation.

Calculation of measured numerical values of densities of metacarpal bones, proximal phalanx, segments of edentulous ridges and numerical data of heights of segments of edentulous ridges of mandibles was done applying $\chi^{2}$ test with comparison of 4 independent samples by McNemar's test.

Student's T test, one-way ANOVA and coefficients of correlations were used for calculation of numerical values of densities of mandibles in P, M1 and M2 regions.

The correlation of functional assessment and patient satisfaction with complete dentures with increased density in mandibular segments after therapy was calculated by Pearson's correlation coefficients. The correlation of retention and quality of the bases of new complete dentures with increased density was calculated by Spearman's correlation coefficients.

The Institutional Review Board of the University approved this study and each participant agreed with an informed consent form before the study began.

\section{RESULTS}

Total skeletal density, established on the basis of $\mathrm{T}$ scores was measured on densitometer, and minimum values were calculated for osteoporotic patients: $\mathrm{T}=-2.5$ $\mathrm{g} / \mathrm{cm}^{3}$ in men and $\mathrm{T}=-2.6 \mathrm{~g} / \mathrm{cm}^{3}$ in women (Table 1). 
Values of BMI were the lowest in osteoporotic patients (Table 2).

The measured values of metacarpal indexes were in upper levels for patients of the control group, but in very low levels for osteoporotic patients (Table 2).

The measured density values of metacarpal bones were as a minimum in women $\left(0.68\right.$ and $\left.0.65 \mathrm{U} / \mathrm{mm}^{2}\right)$ and men $\left(0.77\right.$ and $\left.0.82 \mathrm{U} / \mathrm{mm}^{2}\right)$ of patients with osteoporosis (Table 3 ).

The numerical values of densities of proximal phalanx were no less than 0.51 and $0.52 \mathrm{U} / \mathrm{mm}^{2}$ in osteoporotic women, and no less than 0.53 and $0.56 \mathrm{U} / \mathrm{mm}^{2}$ in osteoporotic men (Table 4).

The measured values of densities in the segments of the first missing molars in mandibles were as a minimum in women $\left(-1.80\right.$ and $\left.-1.81 \mathrm{U} / \mathrm{mm}^{2}\right)$ and in men $\left(-1.19\right.$ and $\left.-1.27 \mathrm{U} / \mathrm{mm}^{2}\right)$ suffering of osteoporosis (Table 5).

Minimum heights of edentulous alveolar ridges were measured in osteoporotic women $(21,84 \mathrm{~mm}$ and $22,39 \mathrm{~mm})$ and in osteoporotic men $(24,90 \mathrm{~mm}$ i 24,96 $\mathrm{mm})$ (Tables 6 and 7).

Positive correlations of the radiographically revealed and measured height loss of the edentulous ridge Y1 and the digital light density in the determined segments of the mandibles (Table 8) as well as of measured height loss of the edentulous ridge Y1 and the BMI (Table 9) were established.

Based on comparison of numerical values that were observed in the analysis of densities of metacarpal bones, proximal phalanges, edentulous ridge segments and numerical data on the edentulous ridge using the $\chi^{2}$ test and McNemar's test results are established: $\chi^{2}$ $=3.8182($ degrees of freedom $\mathrm{v}=11)$ in men with normal bone density, $\chi^{2}=4.0384$ (degrees of freedom $v=$ 12) in women with normal bone density, $\chi^{2}=5.9238$ (degrees of freedom $v=9$ ) in men with osteoporosis, bone, $\chi^{2}=6.2571$ (degrees of freedom $v=11$ ) in women with osteopenia, bone, $\chi^{2}=2.6359$ (degrees of freedom $v=5$ ) in men with osteoporosis, bone, $\chi^{2}=$ 3.8519 (degrees of freedom $v=6$ ) in women with osteoporosis, at the level of probability 0.05 (ie 5\%).

On the basis of $\chi^{2}$ tests it was established that assessed data were relevant and consistent.

Increment of density of mandibular segments after the therapy was significant for Pr and Pl segments $(p<0.01)$. Following administration of calcium and calcitonin in solutions, moderate increment of jaw-bone density $\mathrm{p}<0.05$ and $\mathrm{p}<0.01$, was observed, compensating up to $4 \%$ of bone's mineral loss (Table 10). Increment of solidity of bone in the control group was present but not in significant levels.

The median score on the questionnaire for functional assessment of new complete dentures which pati- ents used after the calcitonin/calcium therapy was 2, and scores ranged from 2 to 3 . There were positive correlations of fit of lower dentures, ability to eat foods, and comfort with the therapy, with increased density in mandibular segments (Tables 11-14).

\section{DISCUSSION}

Osteoporosis is a systemic skeletal disease characterized by reduced bone mass and structural changes of the bone tissue, leading to bone fragility and an increased risk of fracture $(1,2,3,29,30)$. Socio-economic factors and global trends have caused increased number of people suffering of osteoporosis $(1,2,25)$.

According to the literature, the extraction of teeth in the jaw last activated osteoclasts during the first 6 to 24 months $(10,31,32,33)$ with later builds slower but progressive atrophy with reduction of the edentulous ridge. In addition, under certain allegations of professional studies systemic factors have a greater influence on the reduction of the edentulous jaw, with the systemic factors activated immediately and directly after the action of local factors $(3,5)$. In one study where the problematic of osteoporosis was focused 128 edentulous patients with osteoporosis were examined, with use of DXA to determine skeletal density and edentulous ridge resorption around the mental foramen and distally. Based on the results of this study statistically significant correlation between the reduction of the alveolar ridge of mandible and osteoporosis was showed (8). In a similar study conducted in 92 edentulous patients aged between 75 and 85 years, osteoporosis was defined based on the analysis of the panoramic radiographs of patients with the most intensified reduction in edentulous ridges, and statistically significant difference was found in the values of the minimum and maximum measured values of bone mineral density (34). Statistically significant differences in structure and bone density were tested with normal bone density and tested with osteoporosis, however, have not been established in a study performed on 12 edentulous postmenopausal women. Despite of diagnosed persistency of edentulous ridge resorption of the jaw, the presence of osteoporosis is determined solely on the basis of performed scan the hips and the existence of fractures of long bones (7).

In order to determine the total skeletal mineral density in this study only vertebral bone densities were assessed, although, two folded scanning of the lumbar vertebrae (L2-L4) and the scanning of a head of neck of the femoral bone is considered to be "the gold standard" in the diagnosis of osteoporosis because of precision, functionality and yet allowed the radiation dose (35).

In order to determine the absorption-reduction and the height of the edentulous alveolar ridges in this 
Table 1. Distribution of patients' age by different groups of bone mineral density and T values (scores)

\begin{tabular}{|l|c|c|c|}
\hline \multicolumn{1}{|c|}{ Group } & $\begin{array}{c}\text { Number } \\
\text { of patients }\end{array}$ & $\begin{array}{c}\text { Average age } \pm \text { standard } \\
\text { deviation of ages }\end{array}$ & $\begin{array}{c}\text { T value } \\
\text { (score) }\end{array}$ \\
\hline Males with normal bone density & 25 & $67.41 \pm 5.27$ & -0.2 \\
\hline Females with normal bone density & 23 & $65.12 \pm 6.11$ & -0.5 \\
\hline Males with osteopenia & 10 & $69.45 \pm 7.93$ & -1.9 \\
\hline Females with osteopenia & 14 & $67.32 \pm 8.47$ & -2.1 \\
\hline Males with osteoporosis & 29 & $70.27 \pm 8.11$ & -2.6 \\
\hline Females with osteoporosis & 46 & $74.89 \pm 9.05$ & \\
\hline
\end{tabular}

Table 2. Values of metacarpal indexes and BMIvalues in male and in female patients

\begin{tabular}{|c|c|c|c|c|c|c|c|}
\hline \multirow{2}{*}{ Group } & \multicolumn{3}{|c|}{ Metacarpal index — right } & \multicolumn{3}{|c|}{ Metacarpal index - left } & \multirow{2}{*}{ BMI } \\
\hline & Minimum & Maximum & Average & Minimum & Maximum & Average & \\
\hline Males with normal bone density & $48.23 \%$ & $56.65 \%$ & $52.6 \%$ & $48.23 \%$ & $56.65 \%$ & $52.6 \%$ & 24,1 \\
\hline Females with normal bone density & $46.93 \%$ & $52.03 \%$ & $49.7 \%$ & $46.93 \%$ & $52.03 \%$ & $49.7 \%$ & 22,2 \\
\hline Males with osteopenia & $40.08 \%$ & $43.37 \%$ & $41.9 \%$ & $41.03 \%$ & $43.96 \%$ & $42.4 \%$ & 19,9 \\
\hline Females with osteopenia & $38.52 \%$ & $41.14 \%$ & $40.1 \%$ & $39.11 \%$ & $42.12 \%$ & $41.2 \%$ & 18,1 \\
\hline Males with osteoporosis & $31.89 \%$ & $41.93 \%$ & $36.76 \%$ & $30.67 \%$ & $43.02 \%$ & $36.48 \%$ & 18,3 \\
\hline Females with osteoporosis & $29.52 \%$ & $33.41 \%$ & $30.91 \%$ & $29.67 \%$ & $34.17 \%$ & $31.27 \%$ & 16,9 \\
\hline
\end{tabular}

Table 3. Average values of measured densities, expressed in $\mathrm{U}_{\mathrm{mm}}{ }^{2}$, within spongy parts of metacarpal bones

\begin{tabular}{|l|c|c|c|c|c|}
\hline \multirow{2}{*}{ Group } & Number & \multicolumn{2}{c|}{ Right side } & \multicolumn{3}{c|}{ Left side } \\
\cline { 5 - 7 } & $\begin{array}{c}\text { of patients } \\
N\end{array}$ & $\begin{array}{c}\text { Average } \\
\text { value } \\
\bar{x}\end{array}$ & $\begin{array}{c}\text { Standard } \\
\text { deviation } \\
\text { SD }\end{array}$ & $\begin{array}{c}\text { Average } \\
\text { value } \\
\bar{x}\end{array}$ & $\begin{array}{c}\text { Standard } \\
\text { deviation } \\
\text { SD }\end{array}$ \\
\hline Male patients with normal bone density & 25 & 1.94 & 1.23 & 1.98 & 1.14 \\
\hline Female patients with normal bone density & 18 & 1.90 & 1.11 & 1.89 & 1.08 \\
\hline Male patients with osteopenia & 14 & 1.19 & 0.91 & 1.21 & 0.88 \\
\hline Female patients with osteopenia & 20 & 1.15 & 0.89 & 1.11 & 0.92 \\
\hline Male patients with osteoporosis & 25 & 0.77 & 0.71 & 0.82 & 0.69 \\
\hline Female patients with osteoporosis & 30 & 0.68 & 0.74 & 0.65 & 0.72 \\
\hline
\end{tabular}

Table 4. Average values of measured densities, expressed in $U / \mathrm{mm}^{2}$, within spongy parts of proximal phalanx

\begin{tabular}{|l|c|c|c|c|c|}
\hline \multirow{2}{*}{ Group } & Number & \multicolumn{2}{c|}{ Right side } & \multicolumn{3}{c|}{ Left side } \\
\cline { 5 - 7 } & $\begin{array}{c}\text { Nof patients } \\
N\end{array}$ & $\begin{array}{c}\text { Average } \\
\text { value } \\
\bar{x}\end{array}$ & $\begin{array}{c}\text { Standard } \\
\text { deviation } \\
\text { SD }\end{array}$ & $\begin{array}{c}\text { Average } \\
\text { value } \\
\bar{x}\end{array}$ & $\begin{array}{c}\text { Standard } \\
\text { deviation } \\
\text { SD }\end{array}$ \\
\hline Male patients with normal bone density & 25 & 1.71 & 1.12 & 1.78 & 1.14 \\
\hline Female patients with normal bone density & 18 & 1.69 & 1.14 & 1.69 & 1.13 \\
\hline Male patients with osteopenia & 14 & 0.98 & 0.82 & 0.99 & 0.80 \\
\hline Female patients with osteopenia & 20 & 0.95 & 0.78 & 0.98 & 0.79 \\
\hline Male patients with osteoporosis & 25 & 0.56 & 0.71 & 0.53 & 0.69 \\
\hline Female patients with osteoporosis & 30 & 0.51 & 0.74 & 0.52 & 0.72 \\
\hline
\end{tabular}


Table 5. Average values of measured densities, expressed in $\mathrm{U} / \mathrm{mm}^{2}$, of edentulous ridges in regions of missing of the first lower molars

\begin{tabular}{|c|c|c|c|c|c|}
\hline \multirow[b]{2}{*}{ Group } & \multirow[b]{2}{*}{$\begin{array}{c}\text { Number } \\
\text { of patients } \\
N\end{array}$} & \multicolumn{2}{|c|}{ Right side } & \multicolumn{2}{|c|}{ Left side } \\
\hline & & $\begin{array}{c}\text { Average } \\
\text { value } \\
\bar{x}\end{array}$ & $\begin{array}{c}\text { Standard } \\
\text { deviation } \\
\text { SD }\end{array}$ & $\begin{array}{l}\text { Average } \\
\text { value } \\
\bar{x}\end{array}$ & $\begin{array}{c}\text { Standard } \\
\text { deviation } \\
\text { SD }\end{array}$ \\
\hline Male patients with normal bone density & 25 & 2.02 & 1.12 & 2.04 & 1.14 \\
\hline Female patients with normal bone density & 18 & 1.97 & 1.09 & 2.01 & 1.07 \\
\hline Male patients with osteopenia & 14 & -0.85 & 0.82 & -0.82 & 0.84 \\
\hline Female patients with osteopenia & 20 & -0.95 & 0.79 & -0.89 & 0.81 \\
\hline Male patients with osteoporosis & 25 & -1.27 & 0.69 & -1.19 & 0.63 \\
\hline
\end{tabular}

Table 6. Measured heights of edentulous alveolar ridges of mandibles (in $\mathrm{mm}$ )

\begin{tabular}{|l|c|c|c|c|c|c|c|}
\hline \multicolumn{1}{|c|}{ Group } & Number & \multicolumn{3}{c|}{ Right side } & \multicolumn{4}{c|}{ Left side } \\
\cline { 6 - 10 } & $\begin{array}{c}\text { of } \\
\text { patients } \\
N\end{array}$ & $\begin{array}{c}\text { Average } \\
\text { value } \\
\bar{x}\end{array}$ & $\begin{array}{c}\text { Standard } \\
\text { deviation } \\
\text { SD }\end{array}$ & KV & $\begin{array}{c}\text { Average } \\
\text { value } \\
\bar{x}\end{array}$ & $\begin{array}{c}\text { Standard } \\
\text { deviation } \\
\text { SD }\end{array}$ & $\begin{array}{c}\text { KV } \\
\text { Male patients with normal bone density }\end{array}$ \\
& 25 & 26.22 & 2.28 & 8.31 & 26.24 & 3.06 & 8.39 \\
\hline Female patients with normal bone density & 18 & 24.62 & 2.09 & 8.87 & 24.65 & 2.12 & 8.91 \\
\hline Male patients with osteopenia & 14 & 25.03 & 2.82 & 8.24 & 25.08 & 2.84 & 8.29 \\
\hline Female patients with osteopenia & 20 & 25.29 & 2.79 & 8.39 & 25.31 & 2.81 & 8.41 \\
\hline Male patients with osteoporosis & 25 & 24.96 & 0.62 & 2.43 & 24.90 & 2.68 & 2.19 \\
\hline Female patients with osteoporosis & 30 & 21.84 & 2.28 & 12.21 & 22.39 & 1.91 & 7.51 \\
\hline
\end{tabular}

Table 7. Results of the degree of mandibular residual ridge resorption and height of edentulous residual ridge $(p=0.752)$

\begin{tabular}{|c|c|c|c|c|c|}
\hline & \multicolumn{3}{|c|}{$\begin{array}{l}\text { Reduction of edentulous alveolar ridge } \\
\text { of mandible }\end{array}$} & \multirow{2}{*}{$\begin{array}{c}\text { Height of ridge } \\
\text { of mandible } \\
\text { Right }\end{array}$} & \multirow{2}{*}{$\begin{array}{c}\text { Height of ridge } \\
\text { of mandible } \\
\text { Left }\end{array}$} \\
\hline & small & moderate & intensive & & \\
\hline Normal density of bone & 33 & 10 & 0 & $25,24 \mathrm{~mm}$ & $25,44 \mathrm{~mm}$ \\
\hline Osteopenia & 5 & 13 & 5 & $25,16 \mathrm{~mm}$ & $25,19 \mathrm{~mm}$ \\
\hline Osteoporosis & 2 & 12 & 41 & $23,41 \mathrm{~mm}$ & $23,64 \mathrm{~mm}$ \\
\hline
\end{tabular}

Table 8. Correlation between radiological measurement of mandibular edentulous ridge Y1 and optical density of segment of edentulous mandible

\begin{tabular}{|c|c|c|}
\hline & & Y1 \\
\hline Optical Density & Pearson correlation & $-0.049(* *)$ \\
\hline & P value & 0.006 \\
\hline & Number of patients & 89 \\
\hline
\end{tabular}

** Correlation was estimated for probability $\mathrm{p}=0.01$

Table 9. Correlation between radiological measurement of mandibular edentulous ridge Y1 and body mass index

\begin{tabular}{|c|c|c|}
\hline & & Y1 \\
\hline Body mass index & Pearson correlation & $-0.038(* *)$ \\
\hline & P value & 0.009 \\
\hline & Number of patients & 89 \\
\hline
\end{tabular}

** Correlation was estimated for probability $\mathrm{p}=0.01$ 
Table 10. Increment of density of mandibles of patients of the experimental group, in observation period of up-to 4 months

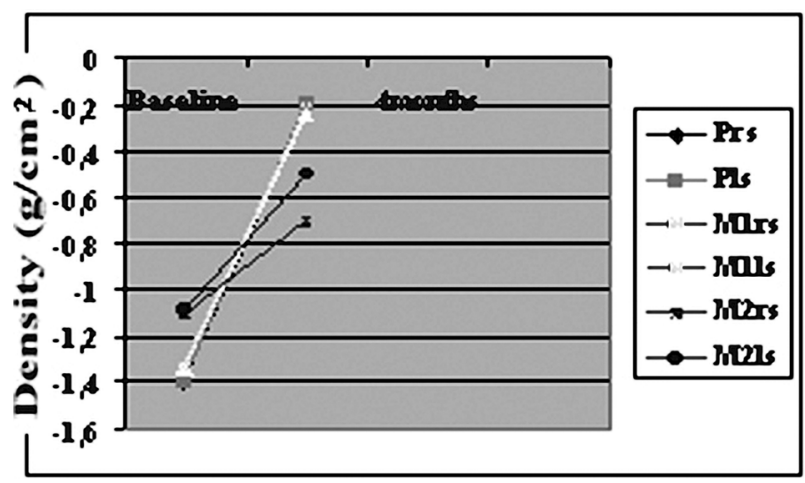

study panoramic radiographs of patients were used, considered as real and meaningful in monitoring and display of height edentulous ridges, although respecting the literature data the measurements of an edentulous ridge height could be performed using a lateral cephalometric radiographs (7). Mandibular bone layers were showed for the purposes of this present study by the panoramic radiographs $(5,7,9,17,34,36-43)$, selecting and marking at the different points of reference, such as median jaw line-"symphysis", lines around the region of the mental foramen, the ridge where the missing first molars or distal point of the retromolar bulge. According to literature data there were not statistically significant difference between the numerical

Table 11. The results of a questionnaire on patients' opinions about their old dentures before therapy with calcitonin and calcium

\begin{tabular}{|l|c|c|c|c|c|c|}
\hline \multirow{2}{*}{} & \multicolumn{2}{|c|}{$\begin{array}{c}\text { Very satisfied } \\
\text { (Good) }\end{array}$} & \multicolumn{2}{c|}{$\begin{array}{c}\text { Fairly satisfied } \\
\text { (Fair) }\end{array}$} & \multicolumn{2}{c|}{$\begin{array}{c}\text { Dissatisfied } \\
\text { (Poor) }\end{array}$} \\
\cline { 2 - 7 } & Number & Percent & Number & Percent & Number & Percent \\
\hline Fit (upper) & 3 & $5 \%$ & 27 & $45 \%$ & 29 & $49 \%$ \\
\hline Fit (lower) & 1 & $1 \%$ & 27 & $45 \%$ & 31 & $53 \%$ \\
\hline Ability to eat foods & 1 & $1 \%$ & 25 & $42 \%$ & 33 & 56 \\
\hline Comfort & 0 & $0 \%$ & 35 & $59 \%$ & 24 & $41 \%$ \\
\hline
\end{tabular}

Table 12. The results of a questionnaire on patients' opinions about their old dentures after therapy with calcitonin and calcium

\begin{tabular}{|l|c|c|c|c|c|c|}
\hline \multirow{2}{*}{} & \multicolumn{2}{|c|}{$\begin{array}{c}\text { Very satisfied } \\
\text { (Good) }\end{array}$} & \multicolumn{2}{c|}{$\begin{array}{c}\text { Fairly satisfied } \\
\text { (Fair) }\end{array}$} & \multicolumn{2}{c|}{$\begin{array}{c}\text { Dissatisfied } \\
\text { (Poor) }\end{array}$} \\
\cline { 2 - 7 } & Number & Percent & Number & Percent & Number & Percent \\
\hline Fit (upper) & 15 & $25 \%$ & 45 & $75 \%$ & 0 & $0 \%$ \\
\hline Fit (lower) & 16 & $27 \%$ & 44 & $73 \%$ & 0 & $0 \%$ \\
\hline Ability to eat foods & 16 & $27 \%$ & 44 & $73 \%$ & 0 & $0 \%$ \\
\hline Comfort & 19 & $32 \%$ & 40 & $68 \%$ & 0 & $0 \%$ \\
\hline
\end{tabular}

Table 13. Evaluation of the technical quality of new complete dentures positioned after therapy with calcitonin and calcium

\begin{tabular}{|c|c|}
\hline Evaluation of retention of base of compete denture & Number of patients \\
\hline Upper complete denture & 21 \\
\hline Good & 38 \\
Fair & 0 \\
Poor & \\
\hline Lower complete denture & 19 \\
\hline Good & 40 \\
Fair & 0 \\
\hline Poor & \\
\hline
\end{tabular}


Table 14. The correlation of functional assessment of a complete denture by a dentist and patient satisfaction with increased mandibular density

\begin{tabular}{|c|c|}
\hline Factors & $\begin{array}{c}\text { Increased density in } \\
\text { segments of mandible } \\
\text { after therapy with } \\
\text { calcitonin and calcium }\end{array}$ \\
\hline Fit (upper) & $0.317 \dagger$ \\
\hline Fit (lower) & $0.624 \dagger$ \\
\hline Ability to eat foods & $0.653 \dagger$ \\
\hline Comfort & $0.748 \dagger$ \\
\hline $\begin{array}{c}\text { Good retention of base of } \\
\text { lower complete denture }\end{array}$ & $0.639 \dagger$ \\
\hline
\end{tabular}

$\uparrow$ Pearson's correlation coefficient

$\$$ Spearman's correlation coefficient

values of edentulous ridge height measured at the center line of the jaw of a digital panoramic radiograph and the lateral-profiled cephalometric radiographs (44). Lateral cephalometric tele-type image, however, does not provide simultaneous insight into the left and right side of the jaw, because of superimposed surfaces to measure the height of the ridge in the lateral-lateral region, particularly on the right, as well as especially on the left side $(5,17)$.

Region where the first lower molar was missing in the lower jaw was chosen in this study for measuring bone density in the jaw as well as to measure the height of the edentulous ridge because it is in everyday professional practice, the biggest problem in the stabilization of lower jaw dentures at present exactly when the absorption of bone around the molars was expressed, or additionally reduced after tooth extraction. There are indications that the region of the first lower molar, among other predictors of the presence of osteoporosis, which may be related to a reduction in the edentulous ridge $(17,40,41)$. The results of this research have just shown that in the bone damaged by osteoporosis, the reduction in the edentulous alveolar ridge is larger and more intense (Table 6, Table 7 and Table 9), which is consistent with the assertions by some authors that in the case of diseases such as systemic osteoporosis, the first signs displayed in the jaws were the reductions of the edentulous ridges $(5,8,9,34,37)$, but in contrast with the results of some recent study (25).

In terms of correlating the edentulous ridge atrophy, reduction and the resorption in the jaw with osteoporosis, there are data to support that osteoporosis leads to specific osteoporotic reduction along the buccal-lingual direction, which in the late stages is revealed as a reduced ridge in the form of a "knife edge" (32, 45). This interpretation, however, cannot be accurately compared with the results of this study, given the fact that suitable form of alveolar ridges would be studied based on a 3-D display of the jaw.

Despite many efforts to prove the causal relationship between the residual edentulous ridge resorption and osteoporosis, a number of the existing situation in everyday dental prosthetic clinical practice can be objectively lead therapist in doubt as to comprehend and interpret the finding that patients with a marked reduction in the jaw ridge had normal bone density or vice versa. This has prompted researchers and the scientific community to try to identify the interconnections of development and intensity of reduction of residual ridges $(17,22,23,28,47)$ with body mass index. In a study conducted on 128 women without teeth, a statistically significant association between high body mass index value and not-reduced edentulous ridges with significantly high values of the vertical dimension was found (22).

Based on the results of the study of 96 edentulous women, a statistically significant difference between the different measurements of height of radiographically presented edentulous ridges in the lower jaw and body mass index were showed (23).

In this study, 99 of the respondents also showed a statistically significant correlation between body mass index and resorption of the edentulous ridge in the sense that edentulous patients with low body mass indexes-BMI also had a small amount of edentulous ridges in advanced reduction process (Table 9).

The metacarpal index is an objective parameter in determining the existence of osteoporosis and assessing the degree of involvement of osteoporosis into the skeleton $(36,40,47)$. In this present study, it was found that the MI values were significantly decreased in osteoporotic patients.

Results on medication of osteoporotic oral bones were favourable in this study. Repeated application of calcitonin and calcium in solutions to oral bone layers, may significantly improve oral bone's condition and denture-supporting area's potential. There should be also prerequisites to assume that therapy by calcitonin and calcium could increase position of remaining teeth of the osteoporotic jaws.

Osteoporotic edentulous mandible should be the first of all oral bones to implicate the solution of calcitonin and calcium. Additionally, respecting the levels of concentration of calcium ions applied, osteoporotic maxillary bone could be treated with the solution of the same kind, in the prolonged period of remedial use. Probable contraindication for local oral application of calcitonin and ionized calcium in solutions should be very intensive reduction of edentulous ridges with alveolar crest positioned under the superficial surface of mylohyoid muscle of the floor of an edentulous mouth. 
It has been suggested in the literature that well-designed questionnaires can be used for assessment of patients' subjective and overall satisfaction with complete dentures (48-51). For the purposes of the present study, it seemed that patient satisfaction with local therapy with calcitonin and calcium, and the wearing of new conventional complete dentures, was equally as important as the validity of the increment of mineral content that is, the solidity of the osteoporotic jawbones after the application of calcitonin and calcium in solution.

The results of this study revealed that more than $27 \%$ of the patients in the experimental group were extremely satisfied with their new complete dentures after the calcitonin/calcium therapy, despite their extensive experience in denture-wearing. Additionally, significant correlations were observed between the retention of lower dentures, ability to eat foods, comfort, and increased density of mandibular segments and local calcitonin/calcium therapy.

In this study, densities of segments of mandibles under surfaces of edentulous alveolar ridges were measured and analyzed. Authors of certain studies advocated for assessment of osteoporosis of mandibles on the basis of thickness of mandibular cortex layers within the bases of mandibles and in the distal angle of mandible-gonion. From diagnostic point of a view it is accepted to judge the proof for diagnosing of osteoporosis in a jaw on the basis of considerations of densities in basal layers which are hard to decompose $(52,53)$. However, from an aspect of clinical treatments and therapy of osteoporotic jaws, it is necessary, above all, to provide data and parameters of layers of jaw-bones which will be in function, and which would be at the forefront, loaded, sooner or later by bases of dentures during chewing. Because of that, the approach applied in this study to focus and to diagnose osteoporotic degradations in segments of missing premolars and molars of mandibles-i.e. in superficial parts of edentulous alveolar ridges, is absolutely approved (28).

\section{CONCLUSION}

Systemic osteoporosis leads to decrease of densities of bones of mandibles and causes reduction of edentulous ridges. Therapy by calcitonin and calcium causes increments of density in jaw-bones and deliberate reduction of edentulous alveolar ridges.
Abbreviations
BMI - body mass index
BMD — bone mineral density
MI - metacarpal index
VBG - heights (in $\mathrm{mm}$ ) of edentulous mandibu-
DXA - dual x-ray absorbtiometry
$\mathbf{P}$ - area of mandible where roots of the second premolars were missing
M1 - area in which roots of the first molars were missing after extractions
M2 - area without roots of the second molars.
3-D display - three dimensional display lar ridges

\title{
Sažetak
}

\section{SISTEMSKA NEMALIGNA OSTEOPOROZA SKELETA I RESORPCIJA BEZUBIH GREBENOVA VILICA}

\author{
Poštić D. Srđan, ${ }^{1,2,3}$ Vujasinović Stupar Nada, ${ }^{4,5}$ Asotić Mithat, ${ }^{3}$ Rakočević Zoran, \\ ${ }^{1}$ Stomatološki fakultet Univerziteta u Beogradu, Srbija \\ ${ }^{2}$ Klinika za stomatološku protetiku, Beograd, Srbija \\ ${ }^{3}$ Univerzitet u Travniku, Farmaceutsko zdravstveni fakultet, Travnik, Federacija Bosne i Hercegovine \\ ${ }^{4}$ Medicinski fakultet Univerziteta u Beogradu, Beograd, Srbija \\ ${ }^{5}$ Institut za Reumatologiju, Beograd, Srbija \\ ${ }^{6}$ Institut za Radiologiju, Beograd, Srbija
}

Uvod. Sistemska osteoporoza oštećuje kosti humanih skeleta u različitoj meri.

Cilj ove studije je bio da se utvrde intenzitet i povezanost promena u gustini skeleta usled osteoporoze i indeks telesne mase (BMI) sa redukcijom bezube mandibule, i da se proceni mogućnost reparacije slojeva u mandibuli praćena porastom mineralnog sadržaja u vilicama pacijenata obolelih usled osteoporoze.
Materijal i metode. U ovoj studiji, 99 bezubih pacijenata sa smanjenom gustinom kosti su sačinjavali eksperimentalnu grupu, a 48 bezubih pacijenata sa normalnom gustinom kosti su bili kontrolna grupa. Godine starosti ispitanih pacijenata i pacijentkinja su iznosile $69,02 \pm 7,9$, u granicama od 53 do 74 godine kod žena, i 69,11 $\pm 7,1$, u granicama od 59 do 76 godina kod muškaraca. Radiografije šaka i ortopantomogrami su 
načinjeni kod svih ispitanih pacijenata. Vrednosti BMI, metakarpalnih indeksa, gustine tela lumbalnih pršljenova (L2-L4), u falangama i u segmentima donjih vilica, a takođe i visine bezubih alveolarnih grebenova su bile ispitane, izmerene i izračunate.

Rezultati. Najmanja vrednost ukupne gustine skeleta je utvrđena kod pacijenata obolelih od osteoporoze na osnovu $\mathrm{T}$ veličine od $-2,5$ kod muškaraca, i -2,6 kod žena. Minimalne vrednosti visina bezubih grebenova (desno/levo, u mm) su bile izmerene i kod žena $(21,84 / 22,39)$ i kod muškaraca $(24,90 / 24,96)$ obolelih od osteoporoze. Upoređivanjima gustina metakarpalnih kostiju, proksimalnih falangi, segmenata (prostora) bezubih mandibula, i na osnovu numeričkih vrednosti izmerenih visina bezubih grebenova, $\chi^{2}=3,81$ je izra-

\section{REFERENCES}

1. Kanis AJ. Osteoporosis. 2nd ed. Oxford: Blackwell Science; 1996. p. 22-7.

2. Birdwood G. Understanding osteoporosis and its' treatment. 1st ed. New York: The Parthenon Publishing group; 1995. p. 37-50.

3. Gueldner SH, Burke MS, Wright HS. 1st ed. Preventing and Managing Osteoporosis. New York: Springer Pub. Co; 2000.

4. Atwood DA. Some clinical factors related to rate of resorbtion of residual ridges. J Prosthet Dent. 2001; 86(2): $119-25$.

5. Poštić S. Analysis of osteoporotic changes in the lower jaws and its clinical significance. [PhD thesis] (In Serbian). Beograd: University of Belgrade; 1998.

6. Devlin H, Feguson MWJ. Alveolar ridge resorption and mandibular atrophy. A review of the role of local and systemic factors. Br Dent J. 1991; 170(3): 101--4.

7. Poštić SD. Promene u mandibuli usled osteoporoze. Stomatološki glasnik Srbije SGS. 2007; 54(1): 16-27.

8. Von Wowern N., Kollerup G. Symptomatic osteoporosis: a risc factor for residual ridge reduction of the jaws. J Prosthet Dent. 1992; 67(5): 656-60.

9. Klemetti E, Vainio P. Effect of bone mineral density in skeleton and mandible on extraction of teeth and clinical alveolar height. J Prosthet Dent. 1993; 70(1): 21-5.

10. Atwood DA, Coy W. Clinical, cephalometric and densitometric study of reduction of residual ridges. J Prosthet Dent. 1971; 26(3): 280-95.

11. Kribbs PJ, Smith DE, Chesnut CHM, Kilcoyne RF. Relationships between mandibular and skeletal bone in an osteoporotic population. J Prosthet Dent. 1989; 62(6): 703-7.

12. Poštić SD. Uslovljenost smanjivanja kostnih slojeva donjih vilica sistemnim promenama skeleta usled osteoporoze. Glasnik ADJ. 2006; 41: 163-76.

13. Balcikonyte E, Balciuniene I, Alekna V. Bone mineral density and radiographic mandibular body height. Baltic Dent Maxillofac J. 2003; 5(4): 137-40.

14. Kribbs PJ. Comparison of mandibular bone in normal and osteoporotic women. J Prosthet Dent. 1990; 63(2): 218-22.

15. Božić M, Hren NI. Osteoporosis and mandibles. Dentomaxillofac Radiol. 2005; 35: 178-84. čunato kod muškaraca, a $\chi^{2}=4,03$ kod žena sa normalnom koštanom gustinom; $\chi^{2}=5.92$ je izračunato kod muškaraca, a $\chi^{2}=6,25$ kod žena sa osteopenijom; $\chi^{2}=$ 2,63 je izračunato kod muškaraca, a $\chi^{2}=3,85$ je izračunato kod žena sa osteoporozom, na osnovu nivoa verovatnoće od 0,05. Posle aplikovanja kalcijuma i kalcitonina $\mathrm{u}$ rastvoru, umeren porast gustine $(\mathrm{p}<0,05 ; \mathrm{p}<$ $0,01)$ je zabeležen, nadoknađujući, na taj način ukupno do 4\% gubitka koštane mase i mineralnog sadržaja u nosećim i potpornim tkivima osteoporoznih donjih vilica.

Zaključak. Sistemska osteoporoza dovodi do smanjenja gustine kosti donje vilice i uzrokuje resorpciju bezubih grebenova.

Ključne reči: osteoporoza; donja vilica; stomatognati sistem; gustina; mineralni sadržaj; kosti.

16. Rosenquist JB,Baylink DJ,Berger JS. Alveolar atrophy and decreased skeletal bone mass of the radius. Int J Oral Surg. 1978, 7(5): 479-81.

17. Poštić S. Osteopenične i osteoporotične promene u segmentima mandibula. Beograd: Zadužbina Andrejević; 2000. p. $14-83$.

18. Baxter JC. Relationship of osteoporosis to excessive residual ridge resorption. J Prosthet Dent. 1981, 46(1): 123-5.

19. Rowe DJ. Bone loss in elderly. J Prosthet Dent. 1983, 50(6): 607-10.

20. Bras J, Van Ooij CP,Van der Akker HP. Mandibular atrophy and metabolic bone loss. Int J Oral Surg. 1985; 14(1): $16-21$.

21. Scandrett FR, Tebo HG, Miller JT, Quigley MB. Radiographic examination of the edentulous patient. I. Review of the literature and preliminary report comparing three methods. Oral Surg Oral Med Oral Pathol. 1973; 35(2): 266-74.

22. Klemetti E, Kroger H, Lassila V. Relationship between body mass index and the remaining alveolar ridge. J Oral Rehabil. 1997; 24(11): 808-12.

23. Knezović-Zlatarić D, Čelebić A, Kobler P. Relationship between body mass index and local quality of mandibular bone structure in elderly individučls. J Gerontol A Biol Sci Med Sci. 2002; 57(9): 588-93.

24. Kovačić I, Celebić A, Knezović-Zlatarić D, Stipetić J. Influence of body mass index and time of edentulousness on the residual alveolar ridge resorption in complete denture wearers. Coll Antropol. 2003; 27(Suppl 2): 69-74.

25. Ozola B, Slaidina A, Laurina L, Soboleva U, Lejnieks A. The influence of bone mineral density and body mass index on resorption of edentulous jaws. Baltic Dental and Maxillofacial Journal. 2011; 13(1): 19-24.

26. Chesnut CH 3rd, Azria M, Silverman S, Engelhardt M, Olson M, Mindeholm L. Salmon calcitonin: a review of current and future therapeutic indications. Osteoporos Int. 2008; 19(4): 479-91.

27. Poštić SD. Medication and positive remodeling of osteoporotic jaws. Balkan Journal of Stomatology. 2008; 12(3): 147-52.

28. Poštić S. Effects of calcitonin and calcium medication in treatment of edentulous osteoporotic mandible. Efekti primene kalcitonina i kalcijuma u lečenju bezubih pacijenata sa osteoporoznim mandibulama. Vojnosanit Pregl. 2013; 70(6): 576-9. 
29. Peck WA, Burkhard P, Christensen C. Consensus development Conference: diagnosis, prophylaxis and treatment of osteoporosis. Am J Med. 1993; 94: 645-50.

30. Osteoporosis prevention, diagnosis and therapy. JAMA. 2001; 285(6): 785-95.

31. Knezović-Zlatarić D, Čelebić A, Lazić B. Resorptive changes of maxillary and mandibular bone structures in removable denture wearers. Acta Stomatol Croat. 2002; 36: 261-5.

32. Krstić M, Petrović A, Stanišić-Sinobad D, Stošić Z. Stomatološka protetika - totalna proteza. Gornji Milanovac: Dečje novine; 1991. p. 113-29.

33. Zarb GA, Bolender CL, Eckert SE, Jacob RF, Fenton AH, Mericske-Stern R. 1st ed. Prosthodontic treatment for edentulous patients. St Louis: Mosby; 2004. p. 44-5.

34. Soikkonnen K., Ainamo A., Xie Q. Height of the residual ridge and radiographic appearance of bony structure in the jaws of clinically edentulous elderly people. J Oral Rehabil. 1996; 23(7): 470-5.

35. White SC, Rudolph DJ. Alterations of the trabecular pattern of the jaws in patients with osteoporosis. Oral Surg Oral Med Oral Pathol Oral Radiol Endod. 1999; 88(5): 628-35.

36. Poštić S, Krstić M, Rakočević Z, Živković R. Kvantitativna analiza promena dimenzija i gustina osteoporoznih bezubih grebenova mandibula, metakarpalnih kostiju i proksimalnih falangi indeksa šaka za vreme izrade totalnih proteza. XVIII Simpozijum protetičara Srbije; 2011 June 16-19; Divčibare. Zbornik radova. str. 53.

37. Poštić SD. Uslovljenost smanjivanja kostnih slojeva donjih vilica sistemnim promenama skeleta usled osteoporoze. Glasnik ADJ. 2006; 41: 163-76.

38. Poštić SD, Krstić M., Goldner B, Rakočević Z. Promene gustina segmenata mandibularnih kostiju žena u sistemskim osteoporozama. XIV Kongres lekara Srbije i kongres lekara otadžbine i dijaspore; 2000 May 21-24; Beograd. Zbornik radova. str. 159 .

39. Poštić SD, Krstić MS, Rakočević Z, Jevremović M., Goldner B, Pilipović NZ, Nastić M. Promene u donjoj vilici kod pacijentkinja sa osteoporozom, pristup i mogućnosti terapije. Acta Medica Semendrica. 1998; 6: 161-5.

40. Poštić SD, Jevremović M, Rakočević Z. Mandibular and metacarpal bone densities in osteoporotic women. J Dent Res. 1998; 77: 721 .

\footnotetext{
Correspondence to/Autor za korespondenciju

Doc dr Srđan Poštić,

Clinic of Dental Prosthetic,

University School of Dental Medicine

Rankeova street 4,

11000 Belgrade, Serbia, e-mail: srdjan.postic@stomf.bg.ac.rs
}

41. Poštić SD, Krstić M, Rakočević Z. Densitometric assessment of mandibular segment and second metacarpal in osteoporotic women. J Dent Res. 1998; 77: 285.

42. Poštić SD, Rakočević Z, Krstić M, Pilipović N. A densitometric appraisal of mandibular segments in osteoporotic subjects. Proceedings of the 2nd Baltic Bone conference; 1997 Aug 28-31; Bornholm, Denmark.

43. Ural C, Bereket C, Şener I, Aktan AM, Akpinar YZ .Bone height measurement of maxillary and mandibular bones in panoramic radiographs of edentulous patients. J Clin Exp Dent. 2011; 3(1): 5-9.

44. Laurina L, Soboḷeva U. Resorption of edentulous alveolar bone. RSU Zinčtniskie raksti; 2008. p. 389-97.

45. Nishimura I, Hosokawa R, Atwood DA. The knife edge tendency in the mandibular residual ridge in women. J Prosthet Dent. 1992; 67(6): 820-6.

46. Hatipoglu H, Ozcan H, Hatipoglu U. Age, sex and body mass index in relation to calvarial diploe thickness and craniometric data on MRI. Forensic Sci Int. 2008; 182(1-3): 46-51.

47. Ward VJ, Stephens AP, Harrison A, Lurie D. The relationship between metacarpal index and the rate of mandibular ridge resorption. J Oral Rehabil. 1977, 4(1): 83-9.

48. De Lucena SC, Gomes SGF, Da Silva WJ, Del Bel Curry AA. Patient's satisfaction and functional assessment of existing complete dentures: correlation with objective masticatory function. J Oral Rehabil. 2011; 38(6): 440-6.

49. Stipho HD, Al-Bisher G. Evaluation of factors pertinent to complete denture treatment satisfaction at King Saud University Dental College's clinic. Saudi Dent J. 1995; 7: 34-9.

50. Fenlon MR, Sherriff M. Investigation of new complete denture quality and patients' satisfaction with and use of dentures after two years. J Dentistry. 2004; 32(4): 327-33.

51. Turker SB, Sener ID, Ozkan YK. Satisfaction of the complete denture wearers related to various factors. Arch Gerontol Geriatrics. 2008; 49(2): 126-9.

52. Cakur B, Dagistan S, Sahin A, Harorli A, Yilmaz AB. Reliability of mandibular cortical index and mandibular bone mineral density in the detection of osteoporotic women. Dentomaxillofacial Radiology. 2009; 38: 255-61.

53. Zlatarić DK, Čelebić A. Clinical bone densitometric evaluation of the mandible in removable denture wearers dependent on the morphology of the mandibular cortex. J Prosthet Dent. 2003; 90(1): 86-91. 